13. Zaichenko Yu. P. Fuzzy models and methods in intellectual systems: textbook. Kyiv: PH Word, 2008. 344 p.

14. Pegat A. Fuzzy modelling and management. Moscow: BINOM, Knowledge laboratory, 2013. 798 p.

15. Yekhlakov Yu. P., Permyakova N. V. Decision-making algorithmic support for software projects risk management // Scientific herald of NSTU. 2014. Vol. 55, Issue 2. P. 122-131.

16. Yekhlakov Yu. P., Permyakova N. V. Fuzzy risk assessment model for software promotion // Business Computer Science. 2014. Issue 3 (29). P. 69-78.

Дата надходження рукопису 28.08.2018

Anzhela Olkhovska, PhD, Associate Professor, Department of Pharmaceutical Marketing and Management, National University of Pharmacy, Pushkinska str., 53, Kharkiv, Ukraine, 61002

E-mail: angelika.olkhovskaya@gmail.com

Volodymyr Malyi, Doctor of Pharmacy, Professor, Head of the Department, Department of Pharmaceutical Marketing and Management, .National University of Pharmacy, Pushkinska str., 53, Kharkiv, Ukraine, 61002 E-mail: malyi.vladimir@gmail.com

Ihor Storozhenko, Doctor of Physical and Mathematical, Professor, Department of Physics, National University of Pharmacy, Pushkinska str., 53, Kharkiv, Ukraine, 61002

E-mail: prof.igor.storozhenko@gmail.com

УДК: 582.711.714:581.47:615.451.1:581.192:615.014.2

DOI: 10.15587/2519-4852.2018.146473

\title{
TECHNOLOGY OF OBTAINING AND INVESTIGATION OF CHEMICAL COMPOSITION OF DENSE EXTRACT OF HAWTHORN FRUITS
}

\author{
(C) N. Sydora, S. Zuikina, A. Kovaleva, L. Vyshnevska
}

На фармацевтичному ринку Украӥни представлені рідкі лікарські форми глоду, які використовуються при комплексному лікуванні серцево-судинних захворювань. Українська флора нараховує понад 30 видів глодів, серед яких достатню сировинну базу мають неофіиійні дикорослі та культурні види.

Мета. Розробити технологію одержання густих екстрактів плодів неофіційних видів глоду та встановити хімічний склад одержаних екстрактів.

Методи дослідження. Для визначення складу БАР густих екстрактів плодів глоду використовували спектрофотометричний метод та метод високоефективної рідинної хроматографії (BEPX).

Результати дослідження. Розроблена технологічна схема одержання густих екстрактів плодів глоду. Встановлено вміст амінокислот, флавоноїдів та гідроксикоричних кислот густих екстрактів плодів С. prunifolia Sarg., C. pseudokyrtostilla Klok. ma C. leiomonogyna Klok.. Вміст флавоноїдів склав від

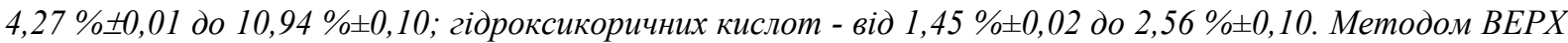
в усіх екстрактах ідентифіковано рутин, хлорогенову і ферулову кислоти. У густому екстракті плодів C. prunifolia Sarg. ідентифіковано апігенін-7-O-рамнозид; C. pseudokyrtostilla Klok. ma C. leiomonogyna Klok. - апігенин-7-O-глікозид, апігенін, лютеолін; C. leiomonogyna Klok. - лютеолін -7-О-диглікозид та квериетин.

Висновки. Одержано густі екстракти плодів C. prunifolia, C. pseudokyrtostilla та C. leiomonogyna. Вперше методом ВЕРХ в екстрактах встановлено вміст флавоноїдів та гідроксикоричних кислот. Проведено порівняльне дослідження амінокислотного складу одержаних екстрактів

Ключові слова: глід, плоди, густі екстракти, хімічний склад, технологія, флавоноїди, гідроксикоричні кислоти, амінокислоти

\section{Introduction}

Genus Hawthorn (Crataegus L.) is one of the polymorphous genus of the Rosaceae L. family and its representatives are widespread in Ukraine and in the world's flora. Having analyzed the raw material base and the degree of study of Ukrainian flora hawthorns, we concluded that attention should be paid to informal wild and cultural species, as promising sources of biologically active substances (BAS).
2. Formulation of the problem in a general way, the relevance of the theme and its connection with important scientific and practical issues

As a result of the study of the chemical composition of unofficial hawthorns, we have established BAS (amino acids, phenolic compounds, organic acids), which have different types of pharmacological activity [1]. 
Therefore, it is relevant to obtain the biologically active substances of hawthorn fruit and to standardize them further.

\section{Analysis of recent studies and publications in} which a solution of the problem are described and to which the author refers

The genus Hawthorn (Crataegus L.) belongs to the subfamily of the Maloidaceae Focke family of Rosaceae Juss. In the world flora, there are more than 1500 species of hawthorn $[2,3]$.

According the results of phytochemical studies in plants of the genus Crataegus L. polysaccharides, amino acids, peptides, proteins, lipids, organic acids, simple phenols, phenolcarboxylic acids, hydroxycinnamic acids, coumarins, procianidines, flavonoids, tannins are identified [4].

The main active compounds of the hawthorn are flavonoids [5]. More than 40 flavonoids have been identified in the leaf, fruits, flowers of hawthorn [6]. The main of which are: kaempferol, quercetin, hyperoside, bioquercetin, 8-methoxykaempferol, apigenin and its glycosides, luteolin and its glycosides, vitexin and its derivatives [7].

Hawthorn flavonoids have a different pharmacological effects [8]. They have a cardiotonic, antihypertensive, antiarrhythmic and sedative effects, increases the amplitude of heart contractions, normalize heart rhythm, accelerate blood circulation, thus improving supply the heart muscle and there is a positive inotropic effect [9]. Due to flavonoids and organic acids, the hawthorn fruit has antioxidant properties [10].

In the pharmaceutical market of Ukraine are both individual and combined drugs of hawthorn [11]. These drugs are used in the treatment of diseases of the cardiovascular system [12]. They are most often prescribed for the treatment of hypertension [13]. Due to non-toxicity of hawthorn drugs, they can be used for a long time for the prevention of cardiovascular diseases [14].
Taking into account the above, it is important to further study the representatives of the hawthorn species in order to find new sources of BAS and the creation of phytopreparations based on them.

4. The field of research considering the general problem, which is described in the article

The most studied are tincture and liquid extract of hawthorn fruit, dense extracts of fruits of unofficial hawthorns were practically not studied, although according to our research, the raw material contains a significant amount of phenolic compounds.

\section{Formulation of goals (tasks) of article}

To develop the technology of obtaining dense fruit extracts of unofficial hawthorn species and to determine the composition of the BAS of extracts for their further standardization.

6. Presentation of the main research material (methods and objects) with the justification of the results

The objects of the study were dense fruit extracts of C. prunifolia Sarg., C. pseudokyrtostilla Klok. and $C$. leiomonogyna Klok.

The dense extracts were obtained from hawthorn fruit harvested in a phase of full ripeness in AugustSeptember 2016.

One of the main conditions taken into account when developing the technology of obtaining dense extractions was to achieve the maximum output of BAS. This is done for selecting the optimal conditions of extraction. For the investigated raw material we have identified the following technological parameters: the degree of grinding, the bulk density, the specific mass, the bulk volume, the porosity, the fenestration, the free volume of the layer, the absorption coefficient of the extractant (Table 1). Technological parameters of raw material determined according pharmacopoeia methods [15].

Table 1

Technological parameters of hawthorn fruits

\begin{tabular}{|c|c|c|c|}
\hline Parameters & C. pseudokyrtostilla & C. prunifolia & C. leiomonogyna \\
\hline The bulk density, $\mathrm{g} / \mathrm{cm}^{3}$ & $0.51 \pm 0.02$ & $0.52 \pm 0.03$ & $0.45 \pm 0.01$ \\
\hline The specific mass, $\mathrm{g} / \mathrm{cm}^{3}$ & $1.35 \pm 0.03$ & $1.50 \pm 0.02$ & $1.49 \pm 0.01$ \\
\hline The bulk volume, $\mathrm{g} / \mathrm{cm}^{3}$ & $0.82 \pm 0.02$ & $0.82 \pm 0.03$ & $0.83 \pm 0.01$ \\
\hline The fenestration & $0.37 \pm 0.03$ & $0.37 \pm 0.02$ & $0.45 \pm 0.01$ \\
\hline The porosity & $0.39 \pm 0.01$ & $0.45 \pm 0.02$ & $0.44 \pm 0.02$ \\
\hline The free volume of the layer & $0.62 \pm 0.03$ & $0.65 \pm 0.01$ & $0.69 \pm 0.03$ \\
\hline \multicolumn{4}{|c|}{ Extraction absorption coefficient, $\mathrm{ml} / \mathrm{g}$} \\
\hline Purified water & $3.4 \pm 0.04$ & $3.1 \pm 0.02$ & $3.2 \pm 0.01$ \\
\hline Ethyl alcogol $50 \%$ & $2.3 \pm 0.02$ & $2.85 \pm 0.01$ & $2.8 \pm 0.02$ \\
\hline Ethyl alcogol $70 \%$ & $2.2 \pm 0.01$ & $2.15 \pm 0.01$ & $2.09 \pm 0.01$ \\
\hline Ethyl alcogol $96 \%$ & $2.03 \pm 0.01$ & $2.01 \pm 0.01$ & $1.98 \pm 0.02$ \\
\hline
\end{tabular}

Experimentally, it was determined that the optimal degree of fruits grinding, in which the highest yield of extractives is achieved, was a size of particles of 1,5-3 mm. As extractant was selected $70 \%$ ethanol $R$, this solvent achieved a maximum output of phenolic compounds, including flavonoids.
In order to prevent the destruction of $\mathrm{BAC}$ and to prevent the use of large volumes of $70 \%$ ethanol $R$ in the development of the technology for obtaining extracts, we offer a percolation method that does not provide for the heating of raw materials.

Preparation of dense extract of hawthorn fruit 
The technological process of obtaining dense extracts consisted of the following stages: the raw material crushing; extraction of BAS; concentration of the extract; packaging, labeling.

Stage 1. The raw material crushing. The fruits were crushed to a particle size of 1,5-3 mm, weighed, placed in cloth bags, divided into 3 equal parts and and placed in a battery of percolators.

Stage 2. Extraction of $B A S$. To the first percolator $70 \%$ ethanol $R$ was added to the "mirror" and extracted the day (Extract 1). Extract 1 was placed in a second percolator and the extractant was added to the required amount, left for extraction per day (Extract 2). Extract 2 was placed in the third percolator with the raw material, $70 \%$ ethanol $R$ was added to the "mirror" and left for another day (Extract 3). The liquid extract was obtained in the ratio of raw material: extractant 1: 1 (brought to a certain volume with $70 \%$ ethanol $R$ to achieve the required ratio of raw material: extractant).
Stage 3. Concentration of the extract. The liquid extracts were evaporated on a vacuum evaporation apparatus to a moisture content of 15 to $25 \%$.

Stage 4. Packaging, labeling. The resulting dense extract was packed in sterile cups of glass and covered with plastic covers.

The technological scheme of obtaining dense extracts of hawthorn fruits is shown in Fig. 1.

The resulting substances were a reddish-brown mass with a characteristic smell.

Mass loss during drying for extracts was determined by the pharmacopoeial method [16]. It was established that for a dense extract of fruit $C$. prunifolia Sarg. the loss in mass during drying ( \%) is 7,38 $\pm 0,12 ; C$.

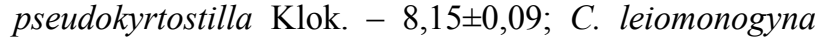
Klok. $-6,25 \pm 0,17$

Definitions were performed three times, the results were statistically processed using the software MS Excel.

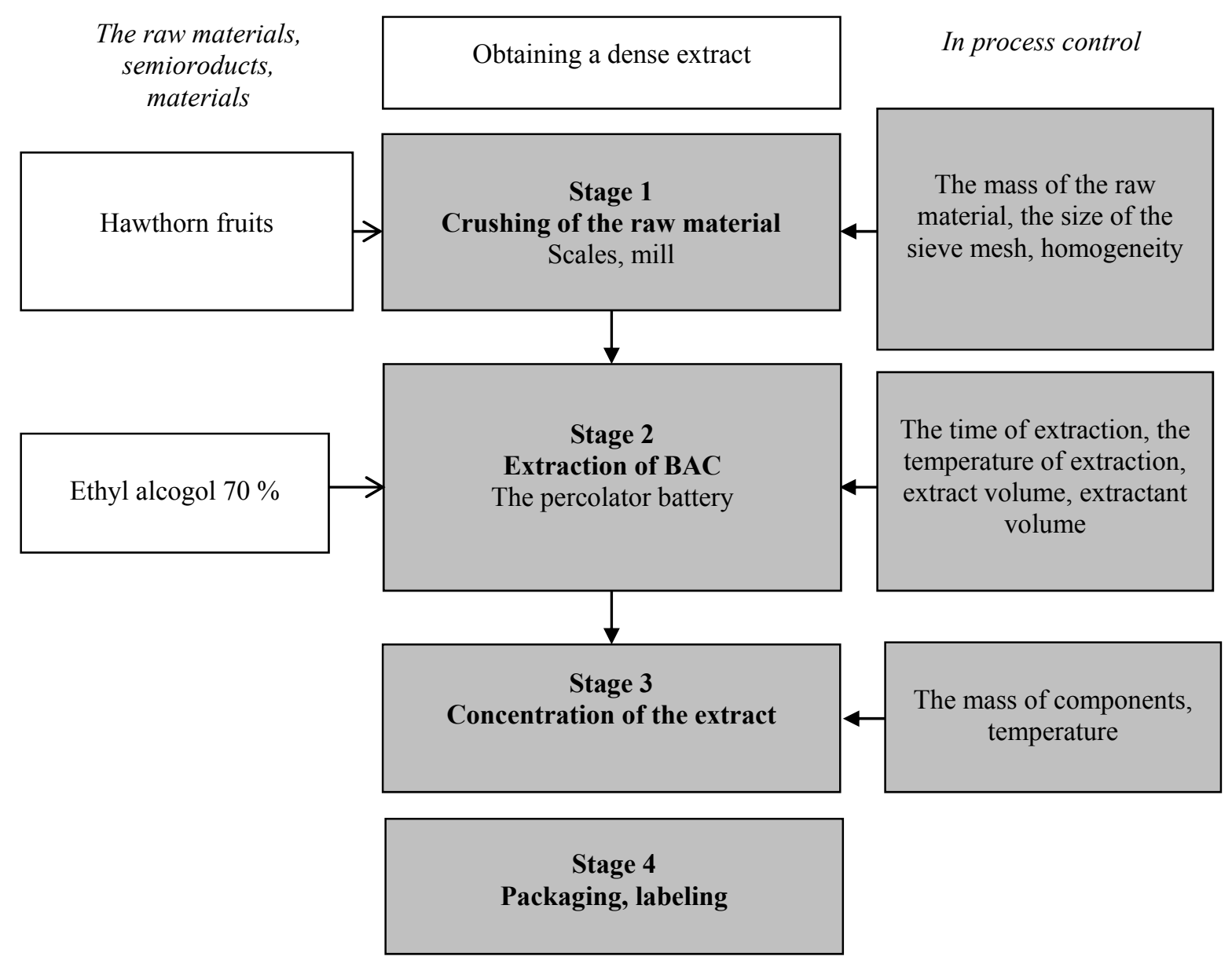

Fig. 1. The technological scheme of obtaining dense extracts of hawthorn fruits

\section{dense extracts \\ Investigation of the chemical composition of}

The content of hydroxycinnamic acids and flavonoids in extracts was determined by spectrophotometric method and high performance liquid chromatography (HPLC) method.

Spectrophotometric determination

Hydroxycinnamic acids
$0.10 \mathrm{~g}$ of the extract was placed in a $10 \mathrm{ml}$ pycnometer, was added $30 \%$ alcohol $P$, dissolved with shaking, adjusted to $10 \mathrm{ml}$ with a solvent and stirred. $1 \mathrm{ml}$ of the resulting solution was placed in a $10 \mathrm{ml}$ pycnometer and added $2 \mathrm{ml}$ of a $0,5 \mathrm{M}$ solution of hydrochloric acid $R, 2 \mathrm{ml}$ of a solution of $10 \mathrm{~g}$ of sodium nitrite $R$ and $10 \mathrm{~g}$ of sodium molybdate $R$ in $100 \mathrm{ml}$ of water $P, 2 \mathrm{ml}$ of sodium hydroxide solution diluted $R$, water $R$ was added to the mark. 
Compensation solution. $1 \mathrm{ml}$ of the stock solution was placed in a $10 \mathrm{ml}$ pycnometer, mixed with $2 \mathrm{ml}$ of $0.5 M$ solution of hydrochloric acid $\mathrm{R}$ and $2 \mathrm{ml}$ of sodium hydroxide diluted solution $R$, the volume of the solution was adjusted to the mark with water $R$, and stirred. Optical density measured at a wavelength of $525 \mathrm{~nm}$, as a comparison solution using a compensation solution [16].

The content of hydroxycinnamic acids X ( \%) in terms of acid chlorogenic is calculated by the formula:

$$
X=\frac{A \cdot 10 \cdot 10}{m \cdot 188}
$$

where A - optical density of the tested solution at a wavelength of $525 \mathrm{~nm} ; \mathrm{m}$ - mass of the test sample extract, in $\mathrm{g} ; 188$ - specific indicator of chlorogenic acid.

\section{Flavonoids}

About $0.25 \mathrm{~g}$ of extract was placed in a $25 \mathrm{ml}$ volumetric flask, dissolved in $20 \%$ ethanol $R$ while stirring, and the volume of the solution in the flask was brought to the mark with the same solvent and stirred (solution B).

$2 \mathrm{ml}$ of solution B added to a $25 \mathrm{ml}$ volumetric flask and $2 \mathrm{ml}$ of $3 \%$ aluminum chloride solution in $96 \%$ ethanol $R$ was added, the volume of the solution was adjusted to $70 \%$ ethanol $\mathrm{R}$ and stirred.
The optical density of the test solution was measured at a wavelength of $415 \mathrm{~nm}$ in a cuvette with a thickness of $10 \mathrm{~mm}$.

Compared solution. A solution containing $2 \mathrm{ml}$ of solution $\mathrm{B}$ is diluted to the mark in a volumetric flask of $25 \mathrm{ml}$ with $70 \%$ ethanol $R$ and mixed.

Under the same conditions conduct a test with $1 \mathrm{ml}$ of solution of PhSS rutin.

Compared solution. A solution containing $1 \mathrm{ml}$ of a solution of the $\mathrm{PhSS}$ rutin is brought into a volumetric flask of $25 \mathrm{ml}$ capacity with $70 \%$ ethanol $R$ to the label and mixed. Before measuring the optical density, the tested solution and the compared solution are filtered through a paper filter, the first portions of the filtrate are discarded [17].

Content of the amount of flavonoids (\%) was calculated by the formula:

$$
X=\frac{A_{1} \cdot a_{0} \cdot 1 \cdot 25 \cdot 25 \cdot 100 \cdot 100}{A_{0} \cdot a_{1} \cdot 2 \cdot 25 \cdot 25 \cdot(100-W)},
$$

where A - optical density of the tested solution; $A_{0}-$ optical density of the PhSS rutin solution; $\mathrm{a}_{1}-$ mass of the test extract, in $g ; a_{0}-$ mass of the PhSS rutin, in $g$; $\mathrm{W}$ - loss in mass during drying, in percentages.

The results of the study of hydroxycinnamic acids and flavonoids are shown in Table 2

Table 2

The results of the study of hydroxycinnamic acids and flavonoids

\begin{tabular}{|c|c|c|}
\hline Substances & The sum of hydroxycinnamic acids, $\%$ & The sum of flavonoids, $\%$ \\
\hline Extract of C. prunifolia Sarg. fruits & $2.56 \pm 0.10$ & $10.94 \pm 0.10$ \\
\hline Extract of C. pseudokyrtostilla Klok. fruits & $2.15 \pm 0.03$ & $3.92 \pm 0.007$ \\
\hline Extract of C. leiomonogyna Klok. fruits & $1.45 \pm 0.02$ & $4.27 \pm 0.01$ \\
\hline
\end{tabular}

As seen from the results of research, the content (\%) of hydroxycinnamic acids in the extracts ranged from $1.45 \pm 0.02$ to $2.56 \pm 0.10$; flavonoids - from $4.27 \pm 0.01$ to $10.94 \pm 0.10$.

Study of phenolic compounds by HPLC method

The studies were carried out on an Agilent 12003 DLC System Technologies (USA) chromatograph, complete with Supelco DiscoveryC18 chromatography column $(250 \times 4.6 \mathrm{~mm})$, sorbent-silica gel. As standard compounds used chlorogenic acid, coffeic acid, ferulic acid, rutin, apigenin, quercetin-3-glycoside, luteolin, quercetin. The standards were introduced in a volume of $5 \mu \mathrm{l}$, test extracts - $10 \mu \mathrm{l}$ [18].

Chromatography was carried out under the following conditions: mobile phase solution $\mathrm{A}-0.1 \%$ solution of $\mathrm{H}_{3} \mathrm{PO}_{4}$ in water $\mathrm{R}, \mathrm{B}-\mathrm{MeOH}$ in ratios of $90: 10,70: 30$ or $20: 80$; feed rate of the mobile phase $0.25 \mathrm{ml} / \mathrm{min}$ [19]. Working pressure of the eluent was 240-300 kPa; the temperature of thermostat column $32{ }^{\circ} \mathrm{C}$; sample volume $-5 \mu \mathrm{l}[20]$. The gradient mode was use (Table 3). Detection parameters: scale of measurement -1.0 ; scan time -0.5 sec.; parameters for removing the spectrum - each peak is $190-600 \mathrm{~nm}$ [21].

The gradient programing

\begin{tabular}{|c|c|c|c|}
\hline Time, min. & $\mathrm{A} \%,(0,2 \% \mathrm{TFA})$ & $\mathrm{B} \% 70 \% \mathrm{MeOH},(0,2 \% \mathrm{TFA})$ & $\mathrm{C} \% 100 \% \mathrm{MeOH}$ \\
\hline 0 & 92 & 8 & 0 \\
\hline 8 & 62 & 38 & 0 \\
\hline 24 & 0 & 100 & 0 \\
\hline 24.1 & 0 & 0 & 100 \\
\hline 29 & 0 & 0 & 100 \\
\hline
\end{tabular}

Phenolic compounds were identified by retention time and spectral characteristics in comparison with standards.
Chromatograms of phenolic compounds of dense extract of hawthorn fruits are shown in Fig. 2-4, the identified compounds are shown in Table 4. 


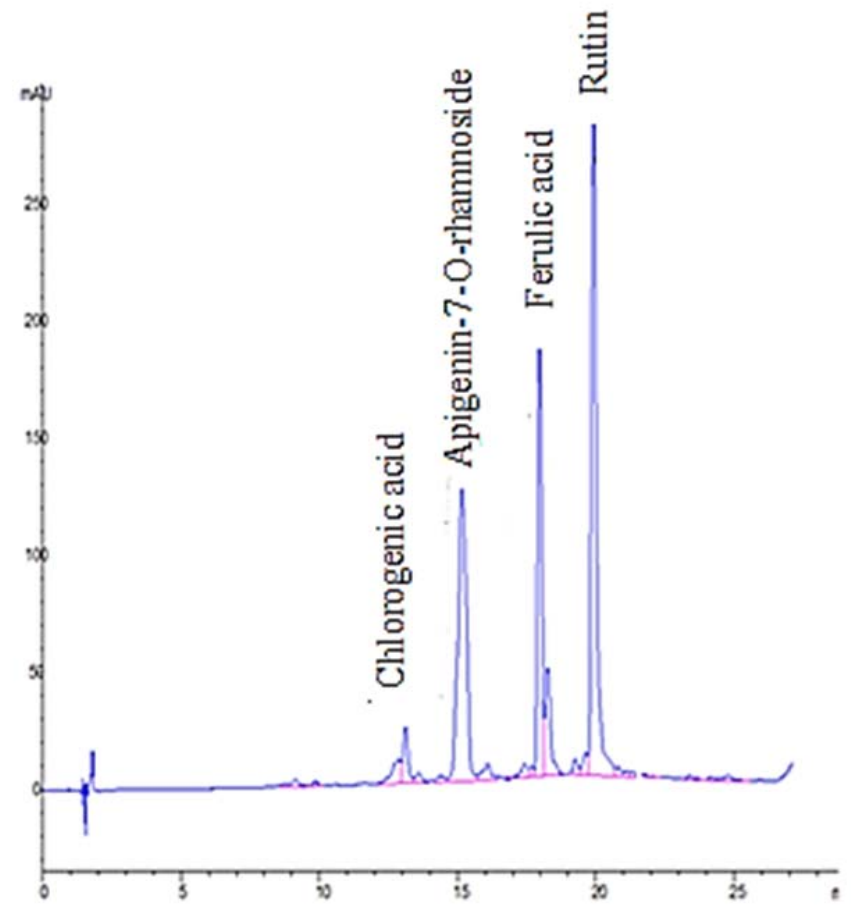

Fig. 2. HPLC chromatogram the fruit dense extract of $C$. prunifolia

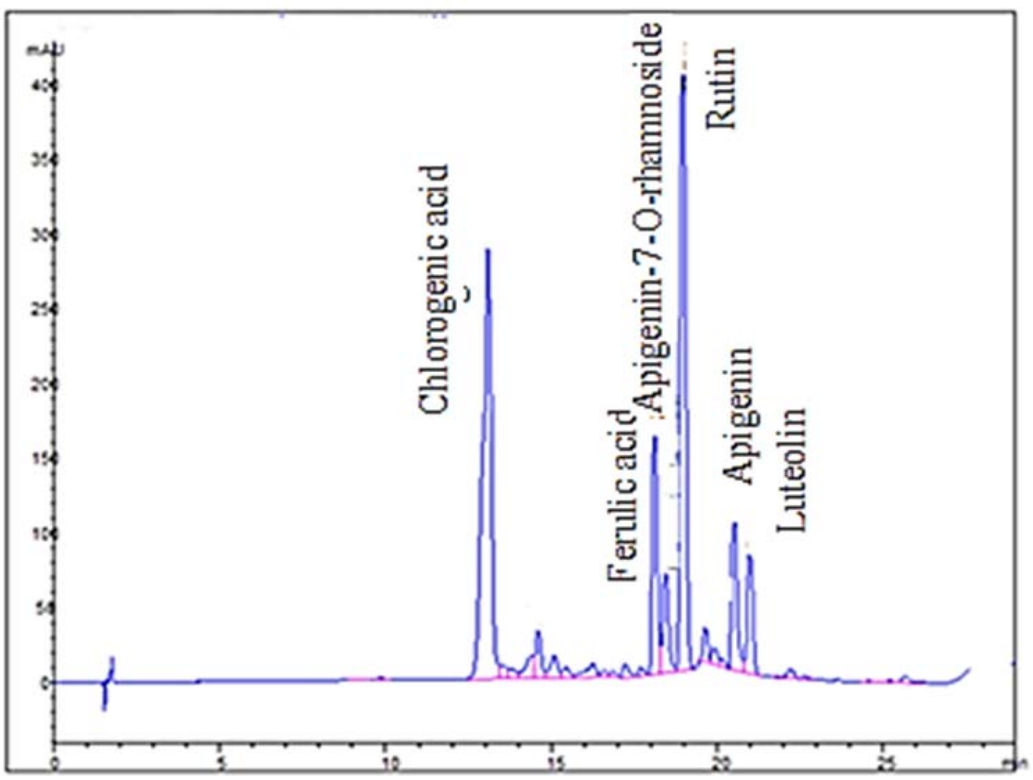

Fig. 3. HPLC chromatogram the fruit dense extract of C.pseudokyrtostilla 


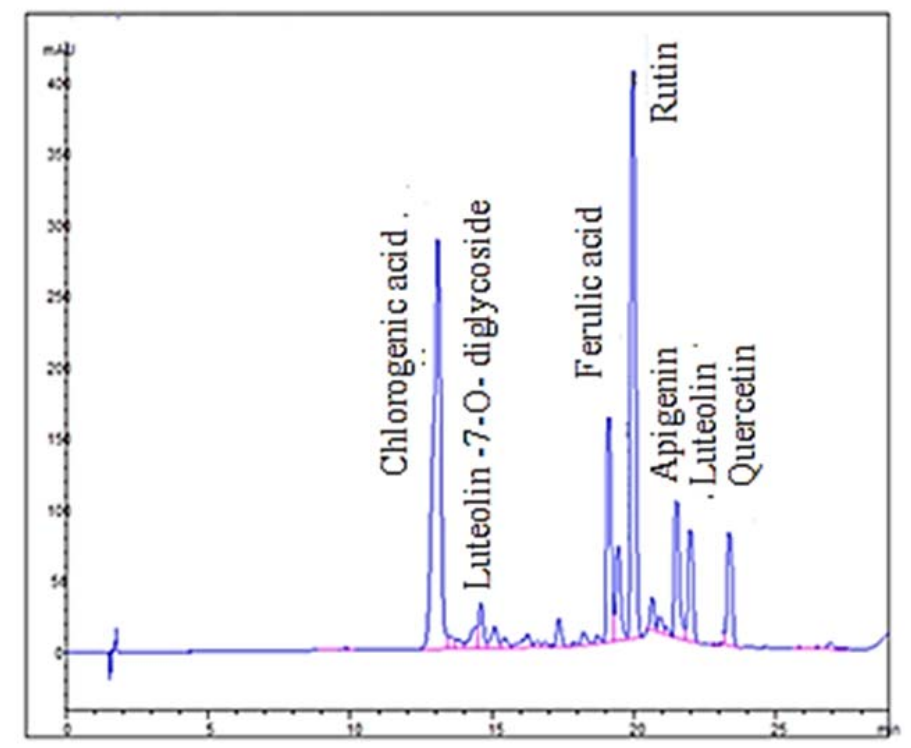

Fig. 4 HPLC chromatogram the fruit dense extract of C. leiomonogyna

Table 4

Phenolic compounds identified in the dense of hawthorn fruit extracts

\begin{tabular}{|c|c|c|c|c|c|c|c|c|c|}
\hline \multirow[b]{2}{*}{ Substance } & \multicolumn{9}{|c|}{ Content, $\mathrm{mg} / 100 \mathrm{~g}$} \\
\hline & $\begin{array}{c}\text { Chloroge } \\
\text { nic acid }\end{array}$ & $\begin{array}{l}\text { Apigeni } \\
\text { n-7-O- } \\
\text { rhamno } \\
\text { side }\end{array}$ & $\begin{array}{c}\text { Ferulic } \\
\text { acid }\end{array}$ & Rutin & $\begin{array}{l}\text { Apige } \\
\text { nin-7- } \\
\text { O- } \\
\text { glyco } \\
\text { side }\end{array}$ & $\begin{array}{l}\text { Apige } \\
\text { nin }\end{array}$ & $\begin{array}{l}\text { Luteo } \\
\text { lin }\end{array}$ & $\begin{array}{c}\text { Luteo } \\
\text { lin -7- } \\
\text { O- } \\
\text { diglyc } \\
\text { oside }\end{array}$ & $\begin{array}{l}\text { Querc } \\
\text { etin }\end{array}$ \\
\hline Extract of $C$. prunifolia fruits & 535.6 & 825.1 & 1523.6 & 1721.0 & - & - & - & - & - \\
\hline $\begin{array}{l}\text { Extract of } C \text {. } \\
\text { pseudokyrtostilla fruits }\end{array}$ & 1205.1 & - & 315.2 & 1805.2 & 202.1 & 476.3 & 252.2 & - & - \\
\hline $\begin{array}{l}\text { Extract of C. leiomonogyna } \\
\text { fruits }\end{array}$ & 1630.4 & - & 415.7 & 1825.2 & - & 175.3 & 152.1 & 223.5 & 165.7 \\
\hline
\end{tabular}

The total content of identified phenolic compounds in extract of fruits $C$. prunifolia Sarg. was $4.6 \%$; fruits $C$. pseudokyrtostilla Klok. $-4.3 \%$; fruits $C$. leiomonogyna Klok. $-4.6 \%$.

It has been established that flavonoid glycosides are predominate in qualitative composition, quercetin derivatives, apigenin and hydroxycinnamic acids predominate in quantification.

In all investigated dense extracts predominates rutin, whose content from the amount of phenolic compounds (\%) was: for the dense extract $C$. prunifolia Sarg. 37.3; C. pseudokyrtostilla Klok. - 42; C. leiomonogyna Klok. - $39.7 \%$. The highest content of chlorogenic acid detected in extract of C. leiomonogyna Klok.

In the dense extract $C$. prunifolia Sarg. contains $2 \%$ hydroxycholic acids and $2.6 \%$ flavonoids; $C$. pseudokyrtostilla Klok. $-1.5 \%$ hydroxycholic acids and $2.8 \%$ flavonoids; C. leiomonogyna Klok. - $2 \%$, hydroxycinnamic acids and $2.6 \%$ flavonoids.

Amino acids

On the basis of the method is extraction of free amino acids from the raw material and acid hydrolysis with HPLC analysis with precolon derivatization of 9fluorenylmethoxycarbonyl chloride and o-phthalic aldehyde with fluorescence detector detection.
The chromatographic separation of the components was carried out on a Agilent 1200 (Agilent Technologies, USA) liquid chromatograph under the following conditions: a Zorbax AAA column of $150 \mathrm{~mm}$ in length and an internal diameter of $4,6 \mathrm{~mm}$, a sorbent grain diameter of $3 \mu \mathrm{m}$; mooving phase $\mathrm{A}-40 \mathrm{mM}$ $\mathrm{Na} 2 \mathrm{HPO} 4 \mathrm{pH}$ 7.8; B-ACN: $\mathrm{MeOH}$ : water (45:45:10, $\mathrm{v} / \mathrm{v} / \mathrm{v})$; gradient separation mode: 0 min. - $12 \%$ "B", 30 min. $25 \%$ "B", 33 min. $25 \%$ "B", 38 min. $30 \%$ "B", 40 min. $40 \%$ "B", 41 min. $80 \%$ "B", 49-60 min. $12 \%$; constant flow rate of $1.5 \mathrm{ml} / \mathrm{min}$; temperature thermostat column $40 \mathrm{C}$. The derivatization was performed automatically using FMOC reagent (Agilent 5061-3337) and OPA reagent (Agilent 5061-3335). Detection of amino acids was carried out using a fluorescence detector [22].

Sample preparation of raw materials. To determine the free amino acids, the weight of the extract was placed in the vial and added $2 \mathrm{ml}$ of aqueous solution of $1 M$ hydrochloric acid $R$, the mixture was kept in ultrasonic bath at $50{ }^{\circ} \mathrm{C}$ for 3 hours.

The determination of the total amino acids was carried out as follows: the weight of extract was added to the vial and added $2 \mathrm{ml}$ of aqueous solution of $6 \mathrm{M}$ hydrochloric acid acid $R$, the mixture was kept for 24 hours in the thermostat at $110^{\circ} \mathrm{C}$ (hydrolysis). $0.5 \mathrm{ml}$ of a hydrolyzate (pre-centrifuged) was evaporated on a 
rotary evaporator and washed three times with purified water $R$ to remove the hydrochloric acid. Resuspended in $0.5 \mathrm{ml}$ of purified water $R$ and filtered through membrane cellulose filters with pores in diameter of $0.2 \mu \mathrm{m}$. The fluorescence derivatives were obtained in an automatic programmable mode before entering the sample into a chromatographic column.

Amino acids were identified by comparing the retention time compounds with a mixture of standard amino acids (Agilent 5061-3334). The quantitative content of amino acids was determined by the area of their chromatographic peaks. The content of linked amino acids was determined by subtracting the content of free amino acids from the total amount. A typical HPLC chromatogram of free amino acids (on the example of $C$. prunifolia fruit extract) is shown in Fig. 5.

Free amino acids identified in the dense hawthorn fruit extracts are presented in Table 5.

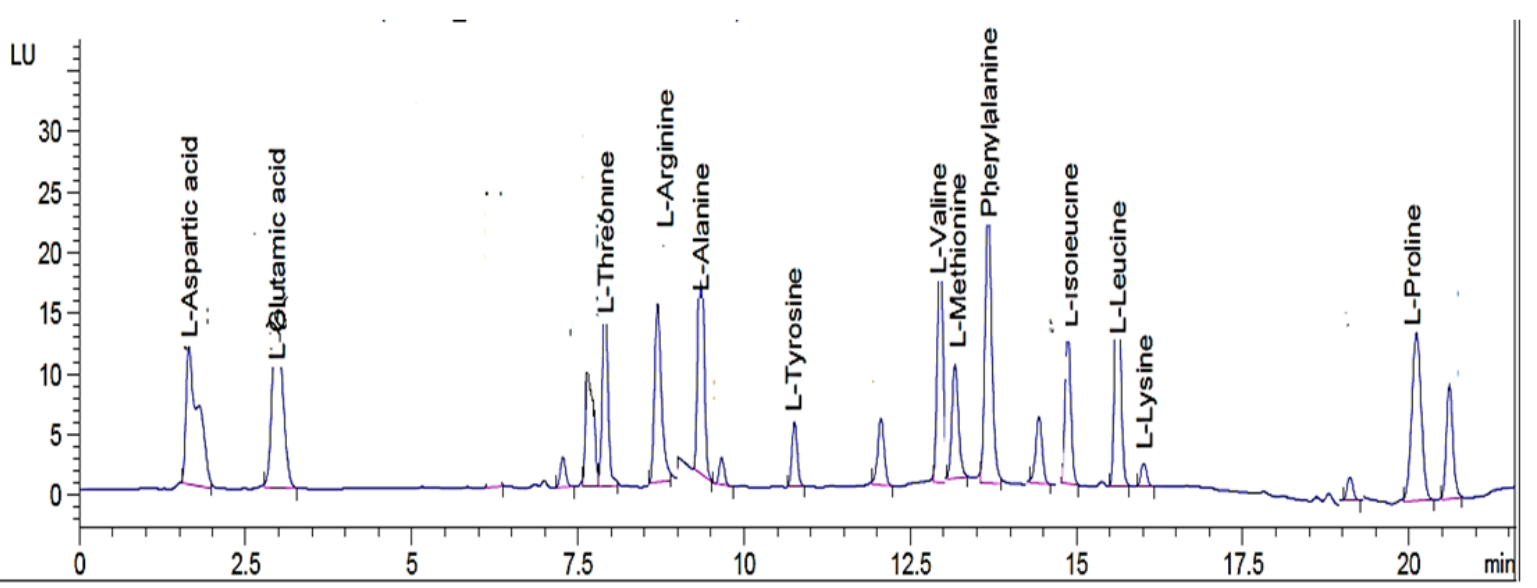

Fig. 5. Typical HPLC chromatogram free amino acids (on an example of C. prunifolia fruit extract)

Table 5

Amino acid composition of dense extract of hawthorn fruit

\begin{tabular}{|l|c|c|c|}
\hline \multirow{2}{*}{ Amino acid } & \multicolumn{3}{|c|}{ Content, mg/100 g } \\
\cline { 2 - 4 } & $\begin{array}{c}\text { Dense extract of } C . \\
\text { prunifolia fruit }\end{array}$ & $\begin{array}{c}\text { Dense extract of } C . \\
\text { pseudokyrtostilla fruit }\end{array}$ & $\begin{array}{c}\text { Dense extract of } C . \\
\text { leiomonogyna fruit }\end{array}$ \\
\hline L-Asparagine & 125.3 & 175.8 & 215.2 \\
\hline L-Threonine & 11.0 & 11.4 & 8.3 \\
\hline L-Serine & 0.0 & 12.3 & 7.9 \\
\hline L-Glutamic acid & 275.4 & 175.6 & 198.4 \\
\hline L-Proline & 5.2 & 0.0 & 7.8 \\
\hline L-Glutamyne & 8.3 & 35.6 & 0.8 \\
\hline L-Methionine & 10.4 & 0.0 & 0.0 \\
\hline L-Leucine & 10.2 & 7.8 & 10.5 \\
\hline L-Tirozine & 5.2 & 24.0 & 5.2 \\
\hline L-Phenylalanine & 11.3 & 9.8 & 14.7 \\
\hline L-Histidine & 0.0 & 10.3 & 7.25 \\
\hline L-Lysine & 12.5 & 0.0 & 175.8 \\
\hline L-Arginine & 320.5 & 386.5 & 667.85 \\
\hline The sum & 784.3 & 851.8 & \\
\hline
\end{tabular}

In the dense extract of fruits of $C$. prunifolia Sarg. and C. pseudokyrtostilla Klok. identified 10 free amino acids, C. leiomonogyna Klok. - 11 amino acids. The highest amino acid content is determined in the dense extract of $C$. pseudokyrtostilla Klok. It has been established that the amino acid composition of dense extracts is differ, depending on the type of hawthorn. So, in the dense extract of $C$. prunifolia Sarg., there are no serine and histidine, while in others these amino acids are identified. Methionine and leucine are not identified in the dense extract of $C$. leiomonogyna Klok. The leucine and methionine are not contained in the extracts of $C$. pseudokyrtostilla Klok.
7. Conclusions from the conducted research and prospects for further development of this field

The technological parameters of raw materials are established and the scheme of obtaining of dense extracts of fruit C. prunifolia Sarg., C. pseudokyrtostilla Klok. and C. leiomonogyna Klok. was developed. For obtained extracts was detected mass loss in drying, which for a dense fruit extract C. prunifolia Sarg. was $7.38 \% \pm 0.12$; C. pseudokyrtosylla Klok. $-8.15 \% \pm 0.09 ; C$. leiomonogyna Klok. $-6.25 \% \pm 0.17$. According to the results of the spectrophotometric determination, defined that according the content of flavonoids and hydroxycinnamic acids the dense fruit extract $C$. 
prunifolia Sarg. the most promising. For the first time, the HPLC method determined chlorogenic, ferulic acids and rutin in all investigated extracts.

Apigenin-7-O-rhamnoside is founded in the $C$. prunifolia Sarg. fruits extract; C. pseudokyrtostilla Klok. -apigenin-7-O-glycoside; C. leiomonogyna Klok. - luteolin-7-O-diglycoside and quercetine. Also, apigenine and luteoline have been identified in
C. pseudokyrtostilla Klok. and C. leiomonogyna Klok. extracts of fruits. In a comparative study of the content of free amino acids of extracts was found that in all investigated substances are dominated asparagine, glutamynic acid and arginine.

The obtained results are the basis for further study of the obtained substances in order to create medicinal drugs.

\section{References}

1. Fenol'nye soedineniya severoamerikanskikh vidov roda boyaryshnik / Goncharov N. F. et. al. // Rossiyskiy medikobiologicheskiy vestnik imeni akademika Pavlova. Issue 3. 2008. P. 150-154.

2. Origin and evolution of subfam. Maloideae (Rosaceae) / Phipps J. B. et. al. // Systematic Botany. 1991. Vol. 16, Issue 4. P. 302-332. doi: http://doi.org/10.2307/2419283

3. Talent N., Dickinson T. A. Polyploidy in Crataegus and Mespilus (Rosaceae, Maloideae): evolutionary inferences from flow cytometry of nuclear DNA amounts // Canadian Journal of Botany. 2005. Vol. 83, Issue 10. P. 1268-1304. doi: http://doi.org/10.1139/b05-088

4. Hamahameen B. A., Jamal B. Determination of Flavonoids in the Leaves of Hawthorn (Crataegus Azarolus ) of Iraqi Kurdistan Region by HPLCAnalysis // International Journal of Bioscience, Biochemistry and Bioinformatics. 2013. Vol. 3, Issue 1. P. 67-70. doi: http://doi.org/10.7763/ijbbb.2013.v3.166

5. Skhiri, F. H., Bahri-Sahl, R., Ammar, S., Fredj, R. B., Saguem, S., Grec, S., Trotin, F. (2009). Polyphenol Contents and Antioxidant Activities of Extracts from Flowers of Two Crataegus azarolus L. Varieties. Pakistan Journal of Biological Sciences, 12 (9), 660-668. doi: http://doi.org/10.3923/pjbs.2009.660.668

6. Study of the chemical constituents of the leaves of Crataegus pinnatifida / Chen J. A. et. al. // Asian Journal of Traditional Medicines. 2008. Vol. 3. P. 80-83.

7. The genus Crataegus: chemical and pharmacological perspectives / Kumar D. et. al. // Revista Brasileira de Farmacognosia. 2012. Vol. 22, Issue 5. P. 1187-1200. doi: http://doi.org/10.1590/s0102-695x2012005000094

8. Schussler M., Holzl J., Fricke U. Myocardial effects of flavonoids from crataegus species // Arzneimittel Forschung. 1995. Vol. 45, Issue 7. P. 842.

9. Functional and antiischaemic effects of monoacetyl-vitexinrhamnoside in different in vitro models / Schüssler M. et. al. // General Pharmacology: The Vascular System. 1995. Vol. 26, Issue 7. P. 1565-1570. doi: http://doi.org/10.1016/03063623(95)00051-8

10. Wild grown red and yellow hawthorn fruits from Tunisia as source of antioxidants / Mraihi F. et. al. // Arabian Journal of Chemistry. 2015. Vol. 8, Issue 4. P. 570-578. doi: http://doi.org/10.1016/j.arabjc.2014.11.045

11. Hawthorn (Crataegus spp.) in the treatment of cardiovascular disease / Furey A. et. al. // Pharmacognosy Reviews. 2010. Vol. 4, Issue 7. P. 32-41. doi: http://doi.org/10.4103/0973-7847.65324

12. Furey A., Tassell M. Towards a systematic scientific approach in the assessment of efficacy of an herbal preparation: Hawthorn (Crataegusspp.) // European Journal of Heart Failure. 2008. Vol. 10, Issue 12. P. 1153-1157. doi: http://doi.org/ 10.1016/j.ejheart.2008.10.003

13. Effects of Hawthorn on the Progression of Heart Failure in a Rat Model of Aortic Constriction / Hwang H. S. et. al. // Pharmacotherapy. 2009. Vol. 29, Issue 6. P. 639-648. doi: http://doi.org/10.1592/phco.29.6.639

14. Georg Belz G., Loew D. Dose-response related efficacy in orthostatic hypotension of a fixed combination of D-camphor and an extract from fresh Crataegus Berries and the contribution of the single components // Phytomedicine. 2003. Vol. 10. P. 61-67. doi: http://doi.org/10.1078/1433-187x-00303

15. Derzhavna Farmakopeia Ukrainy. DP «Ukrainskyi naukovyi farmakopeinyi tsentr yakosti likarskykh zasobiv». Kharkiv: RIREH, 2009. 280 p.

16. Derzhavna Farmakopeia Ukrainy. DP «Ukrainskyi naukovyi farmakopeinyi tsentr yakosti likarskykh zasobiv». Vol. 1. Kharkiv: RIREH, 2015. 1128 p.

17. Kurkina A. V. Metodika opredeleniya kolichestvennogo soderzhaniya summy flavonoidov v trave repeshka aptechnogo. Khimiko-farmacevticheskiy zhurnal. 2011. Vol. 45, Issue 1. P. 31-34.

18. Lenchyk L. V. Determination of phenolic compounds in prunus domestica leaves extract. Scripta Scientifica Pharmaceutica. 2016. Vol. 2, Issue 2. P. 31-35. doi: http://doi.org/10.14748/ssp.v2i2.1302

19. Lenchyk L., Shapoval O., Kyslychenko V. Phytochemical study and determination of pharmacological activities of cherry shoots dry extract // ScienceRise: Pharmaceutical Science. 2016. Vol. 1, Issue 1. P. 40-45. doi: http://doi.org/10.15587/25194852.2016.72746

20. Mraihi F., Fadhill H., Trabelsi-Ayadi M. Chemical characterization by HPLC-DAD-ESI/MS of flavonoids from hawthorn fruits and their inhibition of homan tumor growth // Journal of New Sciences, Agriculture and Biotechnology. 2015. 3. P. 840-846.

21. Lenchyk L. V., Upyr D. V., Ovezgeldiyev D.Phytochemical investigation of bird cherry fruits // Der Pharmacia Lettre. 2016. Vol. 8, Issue 6. P. 73-76.

22. Jámbor A., Molnár-Perl I. Amino acid analysis by high-performance liquid chromatography after derivatization with 9fluorenylmethyloxycarbonyl chloride // Journal of Chromatography A. 2009. Vol. 1216, Issue 15. P. 3064-3077. doi: http://doi.org/10.1016/j.chroma.2009.01.068

Natalia Sydora, PhD, Associate Professor, Department of Pharmacognosy, National University of Pharmacy, Pushkinska str., 53, Kharkiv, Ukraine, 61002

E-mail: sydora2005@gmail.com 
Svitlana Zuikina, PhD, Associate Professor, Department of Drugs Technology, National University of Pharmacy, Pushkinska str., 53, Kharkiv, Ukraine, 61002

E-mail: zujkin.svetlana@gmail.com

Alla Kovaleva, Doctor of Pharmacy, Professor, Department of Pharmacognosy, National University of Pharmacy, Pushkinska str., 53, Kharkiv, Ukraine, 61002

E-mail: allapharm@yahoo.com

Liliia Vyshnevska, Doctor of Pharmacy, Professor, Department of Drugs Technology, National University of Pharmacy, Pushkinska str., 53, Kharkiv, Ukraine, 61002

E-mail: liliiavyshnevska@gmail.com

УДК 616.379:616.831:661.98:577.175.3

DOI: $10.15587 / 2519-4852.2018 .145725$

\title{
REDOX-DEPENDENT MECHANISMS OF BRAIN NEUROPROTECTION OF RATS WITH EXPERIMENTAL DIABETES MELLITUS
}

\author{
(C) O. Temirova, M. Khaitovych, A. Burlaka, A. Vovk
}

Мета. Дослідити ефективність регулювання редокс-залежних механізмів нейропротекиї різних фармакологічних схем $\mathrm{N}$-ацетилцистеїну (NAC) ma мелатоніну (Mel) y головному мозку щурів 3 експериментальним иукровим діабетом 1 типу (ЦД 1).

Методи. Щури з індукованим ЦД 1 отримували NAC (1,5 г/кг), Mel (10 мг/кг) або їх комбінацію (NAC+Mel) протягом 5-ти тижнів. Стан електрон-транспортного ланцюга (ЕТЛ) мітохондрій, швидкість генерування супероксидних радикалів (CP), активність пNOS, концентрацію лактоферину, «вільного заліза», метгемоглобіну, 8-охоG в клітинах головного мозку щурів досліджували методом електронного парамагнітного резонансу (ЕПР) на комп'ютеризованому ЕПР-спектрометрі PE-1307 за температури рідкого азоту ( $(=77 K)$.

Результати. Через 7 тижнів після індукції ЦД 1 швидкість генерування СР мітохондріями головного мозку щурів з ЦД 1 була значно вищою, а активність нейрональної NO-синтази (nNOS) зниженою, порівняно з групою контролю. Було встановлено зменшення активності Комплексу I ЕТЛ мітохондрій та зростання рівня 8-охоG, концентрації «вільного заліза», NO-FeS-білків, концентрації лактоферину ma MetHb, в тканині головного мозку тварин з ЦД 1. Всі досліджувані фармакологічні схеми сприяли достовірному зниженню швидкості генерування CP та відновленню активності пNOS мітохондріями головного мозку. Фармакологічна корекиії NAC/Mel або NAC+Mel сприяла достовірному зниженню рівня 8-охоG та комплексів NO-FeS-білків, нормалізації активності комплексів «вільного заліза» тканини головного мозку щурів з ЦД 1. Терапія NAC також сприяла зменшенню рівня МеtНb, а комбінована терапія NAC+Mel - зменшенню рівня лактоферину головного мозку шурів з ЦД1.

Висновки. При індукції ЦД 1 типу відбувається пошкодження ЕТЛ мітохондрій продуктами неповного розпаду глюкози, щуо проявлясться зниженням синтезу АТФ, підвищенням рівня СР, які генеруються в наслідок порушення механізму транспорту електронів. Терапія NAC ma Mel чи їх комбінації супроводжувалася захистом клітин головного мозку щурів з ЦД 1 від токсичної дї СР, перешкоджаючи порушення функцій мітохондрій, щуо свідчить про нейропротективну дію. NAC та Меl є перспективними лікарськими засобами для профілактики та лікування діабетичної нейропатії

Ключові слова: иукровий діабет, головний мозок, оксидативний стрес, $N$-ацетилцистеїн, мелатонін, мітохондрії, супероксид

\section{Introduction}

Diabetes mellitus (DM) is one of the most common diseases with a steady tendency to increase, "a non-infectious epidemic of the 21 st century" [1]. It is projected that by 2030 the number of patients will reach 552 million $(9.9 \%$ or 1 diabetes patient in 10 healthy adults), and by 2035 - to 592 million (10.1\%) [2]. DM is one of the main causes of cerebrovascular complications. So, the risk of stroke, in patients with diabetes, is 3-4 times higher. In $10 \%$ of cases, vascular complications in patients with DM, lead to lethal effects [3]. The authors of numerous scientific papers in experimental and clinical studies have identified the leading role of oxygen and nitrogen radicals in the pathogenesis of diabetes and its complications, in particular, diabetic encephalopathy $[4,5]$. 